J. of Modern African Studies, 57, 4 (2019), pp. 589-612 (C) The Author(s), 2020. Published by Cambridge University Press. This is an Open Access article, distributed under the terms of the Creative Commons Attribution licence (http://creativecommons.org/licenses/by/4.o/), which permits unrestricted re-use, distribution, and reproduction in any medium, provided the original work is properly cited.

doi:10.1017/Soo22278X1900051X

\title{
The aspiring developmental state and business associations in Ethiopia - (dis-)embedded autonomy?*
}

\author{
Camille Louise Pellerin \\ Department of Government, Uppsala University, Gamla Torget 6, Uppsala \\ Email: camille.pellerin@statsvet.uu.se
}

A B S T R A C T

This article investigates how the Ethiopian People's Revolutionary Democratic Front's (EPRDF) attempt to build a developmental state influenced and shaped its relationships with the Ethiopian private sector. Through a case study of the chambers of commerce system in Ethiopia, the research reveals that the EPRDF's relationship to the private sector was characterised by the twin objectives of (1) curbing the private sector's power to prevent challenges to the EPRDF rule and (2) mobilising the private sector as part of the ruling coalition's developmental state programme. However, these twin objectives, were, in several cases, perceived as mutually exclusive by the EPRDF which, at times, led to a focus on control at the expense of developmental objectives. The ensuing lack of embeddedness posed problems for the operationalisation of the developmental state policies, reducing the EPRDF's ability to institutionalise collaborative relationships with the private sector.

Featuring sustained growth rates of around $10 \%$ between 2005 and 2015 , Ethiopia used to be among the fastest growing economies worldwide, earning it the nickname 'African Lion' (Seid et al. 2016). Between the early 2000 s and $2017,{ }^{1}$ the ruling coalition (EPRDF) pursued the self-proclaimed 'Democratic Developmental State' model (Meles 2011: 27). Emulating development policies used by the Asian Tigers, the EPRDF focused on state-led

* My thanks go to the French Centre for Ethiopian Studies, Addis Ababa, for supporting the fieldwork conducted for this research and to those individuals and organisations whose contributions constitute its base. I would like to thankfully acknowledge comments on previous drafts by Benjamin Chemouni, David Ambrosetti, Nazita Lajevardi and Nigel Thompson. 
development and industrialisation through investment in labour-intensive sectors such as agroindustry and light manufacturing (Meles 2006). While Ethiopia is said to be one of the clearest examples of an aspiring developmental state in Africa, studies found that, like its Asian role models, it was based on authoritarian, not liberal democratic politics (Lefort 2012; Clapham 2018: 1151).

Similar to the Asian Tigers, instead of procedural legitimacy through representation and democratic governance, the EPRDF tried to build political legitimacy on the delivery of developmental outputs (Meles 2011: 169). Formally a coalition of equals, the EPRDF was between 1991 and 2018 de facto led by the TPLF (Tigray People's Liberation Front), a party representing a small ethnic minority from the country's northernmost region. The EPRDF adopted the concept of revolutionary, not liberal, democracy (Bach 2011), in which the EPRDF as the 'vanguard party' ${ }^{2}$ monopolised political decisionmaking and implemented revolutionary politics necessary to promote social and economic transformation (Aregawi 20og: 19of). Despite the achievement of accelerated and sustained economic growth, the outbreak of countrywide anti-regime protests in 2015 revealed the EPRDF's inability to overcome the image of an ethnic minority government, and the ensuing failure to build legitimacy. Moreover, the protesters questioned the EPRDF's claim that it delivered inclusive growth and challenged the EPRDF's model of revolutionary democracy, demanding civic and political rights (Pellerin 2019).

The political crisis led to rapid political changes over the course of 2018 and stimulated evaluations of the developmental state model, including its economic policies. Confirming previous research (Brautigam et al. 2016), workshops and conferences held in 2018/19 revealed that one of the reasons why the developmental state model had come under pressure was the absence of symbiotic relationships between the state under the EPRDF and the private sector. The weakness of institutionalised cooperation posed constraints on the EPRDF's ability to implement its developmental state programme. 3 Instead of promoting Ethiopian private sector development, the EPRDF regime had built its development operations on state-owned enterprises, party endowment funds and party affiliated businesses, as well as the attraction of foreign direct investment, leading Clapham (2018: 1159) to conclude: 'Conspicuously lacking, however, is the alliance between government and the domestic private sector that has been identified as a key driver of Asian developmental states'.

Although the EPRDF is said to have failed in providing consistent support to the private sector in the country, so far there exist very few studies focusing on private sector development under the developmental state paradigm in Ethiopia (Sutton \& Kellow 2010; Gebreeyesus \& Iizuka 2012). The same is true for the role of business associations in the EPRDF's developmental state project. Contrary to the experience of the Asian Tigers (Park 2009), business associations in Ethiopia have often been portrayed as co-opted and unable to represent the interests of their members (Vaughan \& Gebremichael 2011: 23). However, little is known about the process of establishing and sustaining state control, about the EPRDF's rationale behind this move and about the 
ability and willingness of business membership organisations to represent the interests of the private sector.

This article documents the relationships between the state under the EPRDF regime and the chambers of commerce between 1991 and 2017 and investigates how state-business relations have affected the operationalisation of the EPRDF's developmental state project. Based on 14 months of fieldwork, it offers a more nuanced account than often portrayed in the literature. The article demonstrates that, rather than simply repressing the chambers of commerce, the EPRDF's approach has been characterised by the twin objectives of (1) curbing the power of the chambers of commerce and their members to prevent challenges to its rule and (2) mobilising the chambers and their members as part of its developmental state programme. However, the EPRDF's negative stance towards and fear of an independent private sector negatively affected the EPRDF's ability to mobilise the chambers of commerce as part of the state-led development project and resulted in a lack of embeddedness.

The article is based on semi-structured and unstructured interviews, as well as many informal conversations. These were conducted in Addis Ababa and Adama between November 2015 and February 2018 with 33 informants selected through snowball sampling. Interviews were between one and three hours long and several informants were interviewed more than once. Informants included employees working at chambers of commerce and other business associations, employees at relevant public offices, private sector experts and employees at international organisations. ${ }^{4}$ Observations at chambers and chamber meetings, private sector events and workshops complemented the interviews. Archival studies of the chamber newspapers since the 1960 os were used to trace the historical development of the relationship between chambers and different governments in Ethiopia.

The first part of the article provides a brief introduction to the literature on the developmental state (DS), before providing a historical overview of the development of the chamber system in Ethiopia, to contextualise the analysis. The article goes on to explore the role of the chambers in the EPRDF's developmental state project, and the final part maps the interactions between representatives from the chambers and those from the state.

THE CONCEPT OF THE DEVELOPMENTAL STATE IN ASIA AND E T H I O P I A

The concept of the DS was initially developed to explain the rapid processes of economic transformation and industrialisation in Japan (Johnson 1982) and the Asian Tiger economies, South Korea (Amsden 1992), Singapore (Perry 1997), Taiwan (Wade 1988) and Hong Kong (Haggard 1983), between the 195 os and 1980s. Together, the canon of work questioned liberal economic readings (Lal 1998; Krueger 2004) that held that the 'rapid growth in each economy [of the Asian Tigers] was primarily due to the application of a set of 
common, market-friendly economic policies' (Birdsall et al. 1993), and instead, emphasised in each case the state's role in promoting industrialisation and development. While there does not exist one unified definition of the DS, scholars have often identified it by the presence of certain political and institutional characteristics, such as (1) the type of policies adopted; (2) state capacity and state institutions; and (3) state-business relations.

Research has highlighted the strategic use of industrial policies by the DS in Northeast Asia. While consisting of different policy mixes, a common feature of the DS in Asia was that it targeted private sector development, selectively supporting, overseeing and disciplining private entrepreneurs (Johnson 1999; Wade 2003). The EPRDF's capacity to design sound industrial policies and development programmes have repeatedly been cited as reasons for optimism about the operationalisation of a developmental state in Ethiopia (Arkebe 2015; Weis 2016). However, growth has primarily been driven by public investment in construction and infrastructure (Mesfin et al. 2018: 3), despite the EPRDF's efforts to promote manufacturing and private sector development more broadly (Geiger \& Moller 2015).

Several scholars have emphasised the role of the professional bureaucracies in Northeast Asia, that, using merit-based recruitment and operating according to formal rules and regulations, were able to design and implement industrial policies (Castells 1992; Johnson 1995). In the Ethiopian case, although scholars have noted the EPRDF's attempt to professionalise the bureaucracy through comprehensive civil service reforms (Brautigam et al. 2016: 160), valuing loyalty over merit and the dominance of party over state structures were found to reduce state capacity and the ability of the EPRDF to operationalise the DS (Segers et al. 2008; Planel 2014). Reliance on personalised relationships between individual entrepreneurs and bureaucrats has fuelled corruption and reduced the latter's ability to discipline private entrepreneurs (Plummer 2012).

Scholars have revealed that the autonomy of the ruling elites from dominant classes was key for the Asian DS, in order to implement radical policies against the resistance from societal pressures (Castells 1992; Johnson 1995). However, according to Evans, contrary to many other authoritarian regimes, the Asian DS was characterised by embedded autonomy - 'an autonomy embedded in a concrete set of social ties that bind the state to society and provide institutionalized channels for the continual negotiation and renegotiation of goals and policies' (Evans 1995: 59). This was particularly the case with respect to state-capital relations. In Ethiopia, the state has benefitted from a high degree of autonomy and ability to implement policies through coercive means (van Veen 2016). However, its ability to establish collaborative relationships with the private sector to pursue developmental goals has been comparatively weak, partly because the EPRDF built its political settlement on an integration of rural elites and exclusion of urban elites, including the existing business class (Clapham 2018: 1159f).

In the Asian DS, social ties between states and capitalist elites were often embodied in business associations. Business associations became partners, 
albeit junior, of the regimes in power, coordinating for example strategies and activities of their members, ensuring the implementation of development plans, participating in policy elaboration and providing state offices with information about their members to monitor policy implementation (Kim 1997; Park 20og: $842 \mathrm{f}$ ). While fulfilling important functions for the DS, business associations exercised significant pressure on state offices to take concerns of private entrepreneurs into account (E.M. Kim 1997; E.-Y. Kim 1993; Moon 2010). In contrast, in Ethiopia, EPRDF seemed to focus on control rather than institutionalised negotiation, which has reduced business associations' ability to represent the interests of the private sector and decreased their legitimacy in the eyes of their members (Altenburg 2010).

A BRIEF HISTORY OF CHAMBERS OF COMMERCE IN ETHIOPIA FROM THE 194 OS TO 2 OO 3

To investigate the relationships between the EPRDF regime and business associations, the chambers of commerce constitute an interesting case study. They were among the first modern civil society organisations that emerged in the 194 os and used to be the prime representatives of the Ethiopian private sector. During the constitutive phase of the EPRDF regime, the chambers were described as 'formidable members of the civil society and a strong lobbying group for the private sector' (Asrat 2016), while later on they have been portrayed as 'an instrument to disseminate government policies and mobilise support for them, rather than a politically neutral representation of business interests' (Altenburg 2010: 8).

The first chamber, the Chamber of Commerce of Addis Ababa, was founded in 1947 (General Notice 90 1947). Later, branch offices were opened in other urban areas (Minutes of the Annual General Meeting 17 February 1972) and, while representing the business community in the capital, the Addis chamber also functioned as an apex organisation, coordinating the work of other city chambers. During the reign of Emperor Haile Selassie, cooperation with the private sector was promoted and the growing business class was closely connected to imperial circles (Taffara 20o6: 242f). Despite being close to the emperor, chambers represented the interests of the private sector and lobbied, for example, for improvements of the investment climate (Ethiopian Trade Journal 1970: $7 \mathrm{ff}$ ).

After the toppling of Haile Selassie by the Derg, 5 the chamber system was restructured in 1978 , to align it to the new regime's socialist central planning policies (Proclamation No. 148 1978). The relationship between the business community and the Derg regime was tense, businesses were nationalised and private entrepreneurs were portrayed as counter-revolutionaries (Vaughan \& Gebremichael 2011: 18). The Ethiopian Chamber of Commerce was established, and, in cooperation with the Minister of Commerce and Tourism, set up chambers in other urban centres (Proclamation No. 148 1978: Art. 5, 6). Thanks to the establishment of mandatory membership, the Derg-controlled 
chambers ensured the alignment of the business community to the economic policy of the regime (Proclamation No. 148 1978: Art. 15). The politburo also used the chambers to mobilise resources from the business community during the civil war against insurgent movements in the late 1980s (Nigdna Limat No. 53 1988: 8). The Addis chamber lost its former influence to the newly established national chamber and became progressively integrated into state structures. The Nigdna Limat, the Addis chamber's official newspaper, helped to disseminate messages on behalf of the Derg regime (Nigdna Limat No. 59 1989).

Despite the oppression during the Derg era, the business community was quick to reorganise after the EPRDF's victory over the Derg in 1991. Many businessmen felt excluded from the EPRDF regime, that, contrary to prior political settlements based on urban elites and central rule led by ethnic Amhara, ${ }^{6}$ promoted a political settlement based on rural elites and ethnic federalism (Vaughan 2011: 631f). Moreover, the business community questioned the EPRDF's state-led development agenda, that contradicted its ambition for economic liberalisation. Through the chamber system, old economic elites and the growing business class that benefitted from the relative economic liberalisation in the post-Derg era expressed their interests in terms of the country's economic and political organisation. The majority of the chambers' members were from the service sector or from import/export companies, and thanks to their highly educated leaders and financial capital, chambers became powerful interest organisations.

The Addis chamber regained its role as the prime representative organ of the private sector and, during the transition period, the chambers of commerce tried to influence the reorganisation of the country's administrative and political structure (Nigdna Limat 1993: 7). They arranged events to discuss and provide feedback on the policies proposed by the transitional government that affected the private sector (Nigdna Limat 1992a: 7). Moreover, chambers also discussed national politics beyond immediate private sector interests, for example famine relief (Nigdna Limat 1994a: $7 \mathrm{f}$ ), media and freedom of expression (Nigdna Limat Vol. XVII No. 5 1996: 12) and the Ethio-Eritrean war in 1998 (Addis Business Vol. 1 No. 5 1998: 1).

The 1990 sere described by several interviewees as the honeymoon period of the private sector (Interviewee Nr. 81 2016a; Interviewee Nr. 89 2016). Although few of the chambers' attempts to influence politics led to actual changes, they were relatively free in their activism. This changed when the private sector stood behind the more liberal opposition parties during the 2000 and 2005 national elections. Then the EPRDF government increasingly perceived the chambers as a political threat. Around the national elections in 2000, the Addis chamber organised a campaign called 'Addis vote', telling the business community that their vote 'can and will make a difference', urging people to 'vote or forget liberty'. Despite the non-partisan character of the campaign, rumours spread about the then Addis chamber president running for office (Addis Business Vol. 2 No. 12 1999: 1f). The chamber 
organised platforms for candidates from different parties and businessmen to discuss business issues and published numerous articles on the election, but its staff did not run for office (Addis Business Vol. 3 No. 4 2000: 1f).

Given the chambers' increasing activism in the late 1990 os and early 20oos, the EPRDF government tried to intervene in the chambers' internal affairs. An attempt that became publicly known was the initiative in 1998/99 to get rid of the president of the Addis and the Ethiopian chambers of commerce at the time (Addis Business Vol. 1 No. 6 1998: 2). First, the chamber president in office was removed from the presidency of the Ethiopian chamber under unsubstantiated allegations of corruption (Staff Reporter 1999). Then the EPRDF tried to influence the Addis chamber elections through party affiliates in the chamber council, who proposed alternative candidates for the board and the presidency. Although the outgoing president did not want to run for office again, given the conflicts with different public offices during his first term, he was re-elected by a large majority (Addis Business Vol. 2 No. 4 1999: 11; Interviewee Nr. 1212016 ).

The government's attempt to influence the outcome of the chamber elections was futile and reflected badly on it, as details of the failed coup became known publicly (Addis Business Vol. 2 No. 4 1999: 11; Yemisrach 1999). Instead of leading to the silencing of the chambers, the EPRDF's actions increased the chambers' activism. Given its inability to take control over the chambers through infiltration, the EPRDF government finally imprisoned and then exiled the acting chamber president in 2003 (Weis 2016: 261f), and passed the proclamation $341 / 2003$ to restructure the chamber system from the ground up.

The chambers had lobbied for a new legal framework since 1992 and although the Ministry of Trade and Industry started an official drafting process for the new chamber law in 1992, it took 11 years for the law to materialise (Nigdna Limat 1992b: 7). In the meantime, the chambers operated in a legal vacuum, as the Derg proclamation had been invalidated by the country's new constitution. The chambers prepared drafts for a new chamber law, trying to expedite and influence the process (Nigdna Limat 1994b: 6), but they did not succeed (Addis Business Vol. 6 No. 2 2003: 1).

Despite the 11 years of consultative drafting, the 2003 chamber proclamation did not take the position of the chambers into account. The chambers worked closely with the state ministers 7 and technical personnel in the Ministry of Trade and Industry to influence the drafting process, however the executive decisions on the 2003 proclamation were taken by the council of ministers before its submission to the parliament. The Minister of Trade and Industry at that time was one of the architects of the law, and together with the council of Ministers he took the decision to align the chambers to the system of ethnic federalism and to introduce sectoral associations representing the manufacturing sector to reflect developmental state priorities (Interviewee Nr. 89 2016; Interviewee Nr. 1512018$)$. 
The 2003 proclamation testified to the EPRDF's larger push for the operationalisation of the DS in Ethiopia in the early 2000 s and its drafting ran in parallel to the re-education of cadres and bureaucrats under the civil service reform launched in 2001 (Brautigam et al. 2016: 160). The official justification provided by government representatives for passing the proclamation $34^{1 / 2003}$ was technical: aligning the chambers with the new administrative structures of ethnic federalism and making it reflect the importance given to the manufacturing sector within the developmental state project. Government representatives explained:

The chambers' structural administration should follow the new structure. Regions should have regional chambers and sectoral associations. So we needed a new Chamber Proclamation' (Interviewee Nr. 62 2016a).

Before it was only the chambers. Why did we insert the sectoral associations? The chamber only focused on trade. Since the direction in Ethiopia is the developmental state strategy it is important to improve the role of manufacturing. We therefore changed the chambers. (Interviewee Nr. 120 2016)

However, further interviews revealed that besides the technical concerns, regime survival concerns also influenced the 2003 proclamation. Given the chambers' political activism in the 1990 os and early 200os, the EPRDF government wanted to prevent chambers from challenging its rule. A former civil servant remembered for example:

I heard the corridor talks in the Bureau of Trade. They said that the chamber system was captured by chauvinists. The government was concerned that the chambers were anti-government and wanted to clean them. The Ministry of Trade was assigned the role to keep the house in order. Together with others it came up with a complex proclamation to undercut the chamber system. (Interviewee Nr. $812016 b)$

REALIGNING THE BUSINESS COMMUNITY TO EPRDF POLITICS: A NEW

LE GAL FRAMEWORK

The restructuring of the chamber system led to its disintegration and reduced its capacity to represent the interests of the private sector. It created conflicts between different organisations in the chamber system and their leaders, those representing trade and services and those representing manufacturing. Moreover, the restructuring along ethnic lines caused ethnic tensions and increased divides within the business community. While reducing political activism and preventing challenges to the regime, due to the disintegration of the chamber system, the EPRDF regime was unable to mobilise the business community behind the developmental state programme. The ensuing lack of embeddedness constitutes a striking difference between the DS in Northeast Asia and the Ethiopian aspiring DS. The failure to institutionalise state-business relations through the intermediary of strong business associations and the reliance on personalised relationships between individual entrepreneurs and state 
officials fuelled corruption (Plummer 2012). Moreover, contrary to the experience of the Asian Tigers (Lucas 1997: 74), it prevented collective approaches to problem solving in the private sector.

\section{Forceful restructuring}

The main changes introduced by the Proclamation 341/2003 were the integration of sectoral associations into the chamber system and its alignment to federal structures, setting up new chambers of commerce at regional level and sectoral associations all the way down to the woreda level (Directive to Proclamation $34^{1}$ 2004: Art. 3). Existing municipal chambers were restructured to fit the new law and had to integrate sectoral associations, becoming chambers of commerce and sectoral associations (see Figure 1). Sectoral associations were business associations representing the manufacturing sector, rather than the service sector and traders that had traditionally made up most of the members of the chambers in Ethiopia. Examples of sectoral associations established through the 2003 proclamation were the Ethiopian Horticulture Producer \& Exporters Association, the Ethiopian Textile and Garment Manufacturer's Association, and the Ethiopian Leather Industries Associations (ECCSA 2019a). The large majority of sectoral associations were newly established, rather than restructured organisations and the EPRDF influenced their set-up and staffing, to guarantee loyalty to the regime (Interviewee Nr. 126 2016; Interviewee Nr. 129 2016).

Furthermore many of the newly created sectoral associations and regional chambers, while being tasked to represent the economic interests of an entire region or sector, lacked the capacity to recruit members and collect membership fees, were understaffed and had ill-equipped offices (ECCSA 2014: 42). There existed a mismatch between their mandates and their organisational capacities, which was partly due to their recent formation and partly due to their inability to attract strong leaders. Sectoral associations were dominated by small and micro-businesses and though large in number, they lacked technical and financial capacity (Bewket 2013).

Apart from the technical restructuring, the new chamber proclamation was also used to weaken and eliminate business associations that were critical of the regime. The Ethiopian Manufacturing Industries Association, whose structure did not correspond to the sectoral classification stipulated by the new law and its directive, was forcefully restructured (Altenburg 2010: 8). An interviewee disclosed:

The Ethiopian manufacturing association was shut down because it didn't fit the proclamation. But other associations were allowed to continue. The government felt that the manufacturers association didn't play a positive role. They had their own agenda and offices and they tried to influence elections. (Interviewee Nr. $7^{6}$ 2016) 


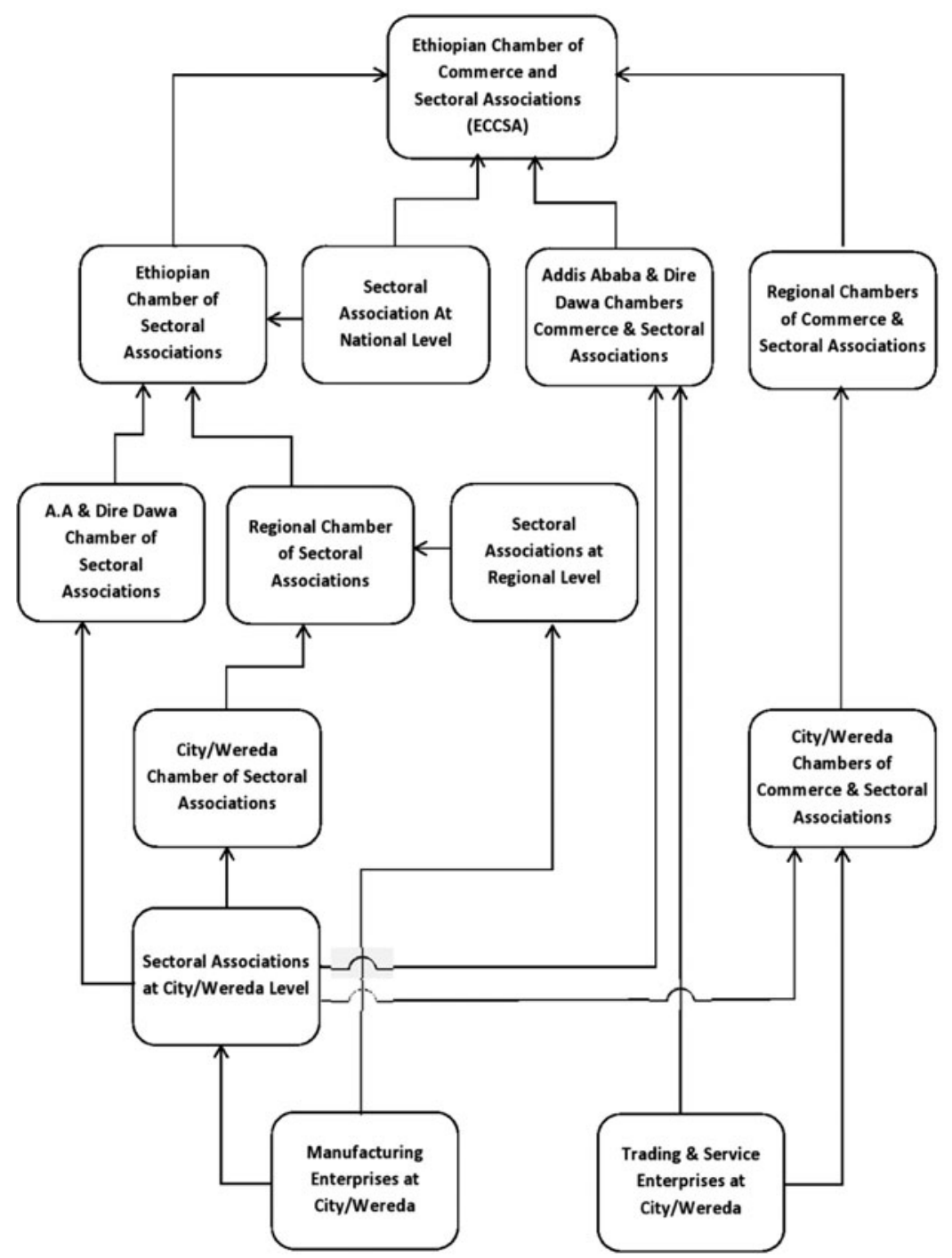

Figure 1. Structure of the Chamber System in Ethiopia (ECCSA 2019b).

The process of restructuring took considerable time and met high resistance, but it was implemented eventually between 2005 and 2007 (Addis Business Vol. 7 No. 20 2005: 1ff). The most visible outcome of the restructuring was the disintegration of the once strong chamber system, as it absorbed the lowcapacity, and more politically aligned, sectoral associations and adapted to the federal structures. New organisations had to be founded and old ones restructured and instead of serving the business community, chamber and sectoral association leaders fought for control over the chamber system itself. 
Subsequently, many reputable businessmen left the system to avoid damage to their reputations and escape the increasing state control exercised over the chambers and sectoral associations (Interviewee Nr. 81 2016b).

\section{The struggle for the mandate of national representation}

The most visible struggle publicly developed between the Addis Ababa Chamber of Commerce and Sectoral Associations (ACCSA) and the Ethiopian Chamber of Commerce and Sectoral Associations (ECCSA), around the question of which one was the rightful representative of the private sector in Ethiopia. The ACCSA comprised the original Addis Chamber and the newly formed sectoral associations, while the ECCSA was a newly created organisation, composed of representatives from the regional chambers of commerce and sectoral associations, seven sectoral associations, the ACCSA and the Dire Dawa Chambers of Commerce and Sectoral Associations (see Figure 1). Given that the ECCSA was made up of business associations and not individual entrepreneurs, it was less directly accountable to the business community and more removed from its day to day activities. The conflict between the ACCSA and the ECCSA was reported on by national media and contributed to the chamber system discrediting itself (Addis Fortune 2009; Birhanu 2016). The two chambers competed for the representation of the private sector and the ECCSA often presented work done or services provided by the ACCSA as its own, fuelling the conflict further (Interviewee Nr. 47 2016; Interviewee Nr. 103 2016).

As the majority of large businesses in Ethiopia were concentrated in and around the capital, the ACCSA had an advantage over the country's other chambers, including the ECCSA. However, to curtail its former influence, the 2003 proclamation formally relegated it to one among many other chambers. While the ACCSA had the larger capacity, the ECCSA had been bestowed with the representative mandate through the 2003 proclamation. The government partnered with the ECCSA, rather than with the ACCSA, as it had designed the voting procedures in the 2003 proclamation to guarantee overrepresentation of EPRDF affiliated associations at national level (Private Sector Development Hub 2013). The ACCSA remained partly affiliated with the urban business elite that did not support the EPRDF. After the restructuring of the chamber system, international donors were told by government representatives to redirect their support of national level private sector development from the ACCSA to the ECCSA, exacerbating the conflict even further (Interviewee Nr. 56 2016; Interviewee Nr. 66 2016).

\section{Ethnic federalism and struggle in the chamber system}

The alignment of the chamber system with the administrative structures of ethnic federalism led to its fractionalisation and the creation of numerous weak chambers. This was particularly so in regions characterised by high shares of agrarian rather than industrial production and low levels of trade 
and commerce, like Benishangul-Gumuz, Gambella, Somali and Afar; regional chambers lacked financial and human capital, due to their low number of paying members and the absence of qualified chamber leaders. To support manufacturing, chambers of sectoral associations were established all the way down to the woreda level. The decentralised structure led to a multiplication of sectoral associations representing very small numbers of businesses and lacking the capacity to represent the interests of their members in an effective manner (Interviewee Nr. 46 2016; Interviewee Nr. 57 2016). Many of the newly created chambers and sectoral associations remained weaker than the ACCSA, whose original constituency was still made up of wealthy urban business elites and whose history and institutional memory dated back to the first half of the 2oth century (Interviewee Nr. 75 2016; Interviewee Nr. 1512018).

The establishment of chambers according to the principle of ethnic federalism contradicted the chambers' original mandate, which was to represent the interests of the business community, not ethnic interests. Moreover, it led to campaigning and voting according to ethnic lines in the ECCSA elections (Teshome 2014; Mikiyas 2016). Rather than revolving around the representation of different business interests, an interviewee reported that 'People support where they come from, not capacity' (Interviewee Nr. 57 2016). In some cases, interviewees also expressed negative views about representatives from other ethnicities, leading for example an interviewee to state: 'They tried to do all possible stupid things in the Tigray chamber. Because they are Tigrayans they think you are afraid of them' (Interviewee Nr. 121 2016). Ethnicisation of conflicts also played out at regional level, with priority being given to the ethnicity of chamber leaders, over their credentials as businessmen. An interviewee shared:

The last elections for the regional chamber [in Oromia], they were wrong. The ballot was open, you just had to raise the hand. He [an ethnic Amhara] won. We all saw he had won. But then the elders in the election committee asked him to be just vice president. They nominated an Oromo as President. (Fieldnotes 2016a)

\section{Struggle among the traders and manufacturers}

While the conflicts between chambers were more visible for the public, the conflicts within the chamber system were at the core of its disintegration. According to developmental state priorities, the proclamation and its directive favoured the representation of the sectoral associations, the manufacturers, over the representation of the traders, who had originally constituted the core of the chambers. The proclamation created double membership for sectoral associations, as they were represented both individually and as associations in the chambers of commerce. This led to voting disadvantages for the service sector and traders (Proclamation No. 341 2003: Art. 7(1), 16(1), 24(1)). Moreover, the directive to the proclamation granted direct membership in the ECCSA to one national and six sectoral associations organised at the 
national level (Directive to Proclamation 341 2004: Art. 5), to ensure the representation of prioritised manufacturing sectors in the chamber system.

Sectoral associations complained about the traders' dominance in the chambers (Interviewee Nr. 126 2016; Interviewee Nr. 129 2016). However, a journalist observing elections at the Addis Chamber in 2013, reported:

Unlike the individual members of the metropolitan Chamber, the sectoral associations are entities created by thousands of micro and small-scale businesses in the craft and services industries. The difference between the two surfaced at the meeting. Their numbers far outweigh the individual members of the Chamber, thus they have the power to be kingmakers. (Bewket 2013)

Rather than taking over the chamber system, the sectoral associations caused its disintegration, creating conflicts among the representatives of the traders and businessmen working in services and those of the manufacturers. Moreover, sectoral associations had little incentive to use the chamber system, as most benefitted from direct connections to state representatives and did not need the chambers as intermediaries for negotiation. An interviewee even reported that - 'The Minister of Industry, Ato Ahmed, I call him every day. I can meet him whenever I want to' (Interviewee Nr. 126 2016). While the statement seems like an exaggeration, field observations confirmed the close working relationship.

As a result of the disintegration of the chamber system, it became marred by corruption scandals. Rather than businessmen, the chamber system attracted people interested in advancing personal careers (Birhanu 2016). A typical problem was chamber presidents disregarding limitation of terms, or moving back and forth between the presidencies of different chambers (municipal, regional, national). Given the exacerbating scandals in the chamber system, its public perception changed. The Ethiopian newspaper Addis Fortune commented for example that, 'These days, whenever chambers are in the limelight it appears that controversy and intense bickering follow' (Asrat 2016). In 2016, the Ministry of Trade needed to intervene on several occasions, as complaints from city chambers about irregularities at regional chamber elections multiplied (Dawit 2016; Samson 2017). An attempt to draft a new chamber proclamation in 2016/17 to improve its structure and address internal conflicts led to a split between the Ministry of Industry and sectoral associations on one hand and the Ministry of Trade and chambers of commerce on the other hand (Interviewee Nr. $15^{1}$ 2018). This shows that the discord between manufacturers and businessmen working in services and trade was also present in the state and casts doubt on the hegemony of the developmental state discourse within the Ethiopian state apparatus.

FROM CONTESTATION TO CO-OPTATION?

The above analysis portrays a complex picture of state-chamber relations, characterised both by the wish of the EPRDF to mobilise the chambers for its 
developmental state project, and its attempt to prevent chambers from contesting EPRDF policies. Moreover, it suggests that the restructuring failed to create a coherent chamber system, leading to discord, not unity. These insights invite a shift in the level of analysis from an organisational level down to individual interactions, to shed light on how different parts of the state related to different parts of the chamber system, and to investigate how far chamber of commerce and sectoral associations operated as representatives for the private sector.

\section{The lasting impact of the chambers' political activism}

The chambers' political activism in the 1990 os and early 2000 led to persisting mistrust between them and the EPRDF government, despite the chambers' efforts to improve the relationship (Interviewee Nr. 75 2016). State representatives explained that the relationship with the chambers had improved (Interviewee Nr. 62 2016a; Interviewee Nr. 107 2016), but the interactions between the chambers and the state confirmed that the latter still feared the chambers' potential power and tried to keep them in place.

One example was the naming of the first public private partnership forum. While the chamber wanted to name the forum 'dialogue forum', government representatives insisted on 'consultation forum'. A former chamber leader involved in the negotiation explained:

I wanted the forum to be called dialogue, not consultative forum. Consultation means you consult but that's it. The Minister of Trade and the State Minister were open about this suggestion. But the Ministers' hands were tied. There was a legal adviser at that time. He tried to please his political bosses. He said no. (Interviewee Nr. 89 2016)

The former adviser explained the government's reasoning as follows:

Dialogue means that one party wants to snatch something forcefully. Dialogue doesn't correspond to the normal procedure. People talk without permission of the chairman. (Interviewee Nr. 62 2016b)

While not directly confirming the allegations made by the chamber leader, the wording chosen by the legal adviser indicated the EPRDF's fear that the chambers could try to dominate the forum and impose their vision of private sector development on it.

Although interviewees felt that, since the restructuring, the EPRDF government reverted to indirect means of control rather than open repression as in the early 2000s, they did not doubt that government representatives would intervene if the chambers became too independent (Interviewee Nr. 20 $2016 a$; Interviewee Nr. $812016 b$ ). The mechanisms with which the government controlled the chamber's internal affairs were informal and difficult to trace. According to interviewees, interventions consisted of direct orders from relevant government officials to specific people in the chamber: 
No one wants to talk about the government influence. But it happens usually through a phone call. Then no one wants to admit to have received such a call and even less that they acted upon it. (Interviewee Nr. 132 2017)

They [the government] just give the chambers a phone call to make sure the chambers work in the interest of the government. They are regulated through direct order. (Interviewee Nr. 1112016 )

\section{Designing an EPRDF-aligned private sector}

To avoid contestation from members of the business community, the EPRDF not only restructured and weakened their associational system, it established a system of domination over the private sector, 'making it dependent on, or at least supportive of, the incumbent regime' (Weis 2014: 270). The EPRDF government established mechanisms to foster party affiliation among all levels of private sector actors, and dependence of businesses on public services was created to guarantee loyalty.

Micro and small enterprises were linked to the EPRDF through the provision of inputs for their operations. State institutions such as the small and microenterprises agency, the TVET agency and the cooperatives agency, provided training, material inputs and finance for small-scale entrepreneurs. Alternative private service providers had been crowded out, leaving the monopoly to the state (Spielman 2008; Berhanu 2013: 1481). This favoured the emergence of an EPRDF-loyal SME sector and, according to an article in Addis Business, 'under the camouflage of the enterprises the government went on utilizing its members as significant input to build political muscle of the ruling party' (Shitahun 2015: 7).

To be able to operate, several medium- and large-sized enterprises reported the need for EPRDF patrons. Without such patrons, they felt it was difficult to renew licences, acquire permits for operation or receive support for credits and access foreign currency. Direct personal connections to the ruling elite were perceived as key, reducing the need for businessmen to use business associations as intermediaries and thereby making organisations like the chambers somewhat redundant. An interviewee explained:

Here in Ethiopia you have to rub shoulders if you work in business. You don't have to be a party member but you need a Godfather to bring up your issues and mentor you. The higher you go in business, the closer you have to be to the political machinery. (Interviewee Nr. $812016 a$ )

An attempt at the Ethiopian Investment Commission (EIC) to change such patterns and select domestic investors using a merit-based, rather than loyalty-based procedure revealed the degree to which businessmen had adapted to neo-patrimonial structures. An interviewee at the EIC reported:

The existing private sector is politically charged. I get applications where people refer to their connections. They mention names or they make ethnic allusions. 
Most public institutions operate on ethnic and political affiliation and this is a problem. (Interviewee Nr. 1532018 )

As the goodwill and support of public offices and civil servants was perceived to be of key importance for businessmen, businessmen often prioritised their relationship to state officials over participation in chamber activities. Given their previous history of conflict with the EPRDF government, some interviewees even held that affiliation to the chambers could be detrimental for businessmen (Interviewee Nr. $812016 \mathrm{~b}$ ). In the words of a respondent:

People laugh at the chambers. They go directly to the corridors of power and bypass the chambers. Only those with connections get things done. Going via the chamber could even be a disadvantage depending on whom you want to meet. (Interviewee Nr. 132 2017)

\section{Co-optation, cooperation, coexistence and contestation}

While the above analysis confirms that chambers of commerce have been strictly controlled by the EPRDF from the early 2000 s onwards, chambers also received pressure from their members to represent business interests. Therefore, chambers' loyalty to the EPRDF was not infinite and interactions between state and chamber officials ranged from co-optation to contestation over various forms of cooperation and coexistence, changed over time and depended on the respective interlocutors. While the sectoral associations worked closely with the Ministry of Industry and often complained about the Ministry of Trade and its favouritism towards the chamber structures representing traders (Interviewee Nr. 126 2016), the latter worked more closely with the Ministry of Trade and reported more problems with the Ministry of Industry (Interviewee Nr. $15^{1}$ 2018).

Many interactions between the chambers and sectoral associations and state organisations testified to co-optation. Particularly the ECCSA and sectoral associations appeared as supporters of the EPRDF government. Public display of support to the government went as far as the ECCSA appointing Ethiopia's president as its patron in 2016 (Interviewee Nr. 103 2016). The close collaboration between the ECCSA and state organisations harmed the chamber system, as citizens and businessmen felt that the chambers were working for the EPRDF, rather than their members, and claimed:

Nowadays there is almost a complete merger between the government and the chambers. (Interviewee Nr. $812016 a$ )

They made the Ethiopian President the patron of chamber. I mean now they prove that they are the government. (Fieldnotes 2016a)

Rather than pushing an agenda separate from the EPRDF, chambers gave primacy to EPRDF-prioritised sectors. This meant primarily serving the interests of small and micro enterprises and focusing on manufacturing and agroindustry, rather than trade and services (Interviewee Nr. 55 2016), leading to a 
neglect of the interests of some of the chambers' members (Interviewee Nr. 39 2016). The inability of the chambers to clearly push the agenda of the private sector beyond the areas prioritised by the government, reduced the chambers' legitimacy in the eyes of some of their members (Fieldnotes 2016b). Interactions testifying to co-optation were particularly frequent in the case of the new chamber structures established through the 2003 proclamation, especially the sectoral associations representing manufacturing and the ECCSA, rather than the original chambers of commerce structures representing trade and services.

Despite the sizeable control that the EPRDF government was exercising over the chamber system, the close link between chamber and state structures allowed parts of the chamber system to influence state organisations and actors through formal and informal channels (Interviewee Nr. 6o 2016; Interviewee Nr. 82 2016). Chambers of commerce and sectoral associations engaged in mutually beneficial interactions with state organisations, pushing the agenda of their members within EPRDF-sanctioned sectors and policies. Formal consultation structures between the Ethiopian government and the private sector were institutionalised in 2010 through the signing of a memorandum of understanding for a public private consultative forum (Ministry of Trade and Industry (MoT), Girma Birru Minister \& Ethiopian Chamber of Commerce and Sectoral Associations 2010). Sectoral meetings took place four times a year, while general public-private consultative forums took place twice a year, testifying to the prioritisation of the manufacturing sectors and sectoral associations over services and trade and chambers of commerce in the EPRDF developmental state project. Interviewees reported that many of the forums led to agreements (Interviewee Nr. 62 2016b). Although the implementation of agreed action points often lagged behind, interviewees from the chambers and the government felt that this depended on the relative lack of capacity of state bureaus/ ministries, rather than their willingness: 'The government agrees with 6o or $70 \%$ of the issues we present, but implementation is difficult. Our success rate is only 40\%' (Interviewee Nr. 57 2016). Given the relative inefficiency of formal channels to yield concrete outputs, chambers and sectoral associations used informal channels to directly influence government representatives. They reported using their personal connections to government officials to push the agenda of the private sector. Issues they brought up included, for example, suggestions for policy change and input into government plans, and requests for technical and/or material support and reporting of market failures and misconduct in public offices (Interviewee Nr. 20 2016b; Interviewee Nr. 70 2016). The same patterns in terms of actors held true for cooperation as for co-optation, given that state organisations cooperated less willingly with the old chamber structures (Interviewee Nr. 104 2016). However, the relative weakness of many of the newly established organisations reduced their ability to become strong development partners for the EPRDF.

Large parts of the chambers sector that represented the interests of trade and services and pre-dated the 2003 proclamation were forced into coexistence, to 
prevent them from influencing policymaking and the work of state organisations, and denying organisations and actors access to state structures, especially where co-optation was costly and did not come with direct benefits, as in the case of the ACCSA. This prevented the parts of the chamber system perceived as too critical by the EPRDF government from influencing state actors and policymaking. While the ACCSA was the clearest case of an organisation being forced into coexistence, other city and regional chambers also complained of a lack of access to state structures (Interviewee Nr. $202016 a$; Interviewee Nr. 40 2016). Interviewees at the ECCSA and sectoral associations often constituted an exception to the rule (Interviewee Nr. 103 2016; Interviewee Nr. 129 2016). Chambers were not able to use their forced independence, as coexistence meant carrying out activities without directly interacting with state structures, but keeping the state informed. Co-existence often took the form of service provision to members (Interviewee Nr. 42 2016; Interviewee Nr. 92 2016), including, for example, publishing the trade directory; advocacy and lobbying for private sector development; issuing certificates of origin and authentication of documents; providing capacity building; and organising trade fairs and bazaars.

Given the repressive political climate, chambers, since their reorganisation in 2003, have not engaged in public protests. Instead, they have concentrated on discussing policies and government strategies that influenced private sector development, rather than engaging in broader political issues. Most interviewees expressed that they contested any state-led development agenda of the EPRDF where it harmed the private sector, explaining that as long as they focused on private sector issues, they did not have to fear negative repercussions from their criticism (Interviewee Nr. 20 2016c; Interviewee Nr. 38 2016; Interviewee Nr. 104 2016). However, field observation indicated reluctance of the chambers to criticise the EPRDF's private sector development policies and revealed defensiveness on the side of government representatives when such criticism was brought up (Fieldnotes $2016 c, 2016 d, 2016 e$ ). Contestation primarily took the form of verbal or written criticism. The ACCSA was more vocal than any other chamber or sectoral association. Awareness raising was used to put pressure on the government to address the issues brought up by the chamber. While state control over the media posed limits to this strategy, the chamber newspaper, available online and distributed in print to the ACCSA's members, was an important tool to sustain it. As an interviewee explained, 'We have more freedom in our newspaper than on radio or TV. Some printing houses, especially the big ones that are government controlled, refuse to print critical things. But we don't use them' (Interviewee Nr. 38 2016). Policies described as particularly harmful for private sector development were the land lease legislation, taxation policies and the registration of businesses (ECCSA 2014: 35ff; Mesfin 2015). The chambers also exposed the state's practical shortcomings, naming corruption and the failure to operate according to the existing legal framework as key issues (Interviewee Nr. 40 2016; Interviewee Nr. 59 2016). 
This article argues that the EPRDF's relationship to the chambers of commerce was characterised by the twin objectives of (1) curbing the power of the chambers of commerce to prevent challenges to its rule and (2) mobilising the chambers as part of its developmental state programme. The analysis revealed that while it achieved the first objective, the focus on controlling the chambers negatively affected the EPRDF's ability to mobilise them as part of the operationalisation of its developmental state project. Compared to its Asian role models, the state, under the EPRDF regime, lacked embeddedness and this reduced its ability to push its developmental state programme. While its autonomy allowed the EPRDF regime to take decisions against the interests of the private sector, often necessary to implement its ambitious policies, it was unable to effectively mobilise the private sector behind its developmental state programme.

The restructuring in 2003 created chamber structures representing the EPRDF's focus on manufacturing and agroindustry. However, many of those new organisations were weak, posing limits to their ability to contribute to the operationalisation of the EPRDF's developmental state programme. Chambers were seldom seen as legitimate representatives of the private sector, and their relative weakness negatively affected their ability to influence state policies in favour of their members. The deficiency of institutionalised mechanisms of negotiation between the EPRDF regime and the private sector favoured patron-client relationships and opened possibilities for corruption. Big businesses, particularly, used direct contacts to negotiate with state actors instead of going through the chambers. Party affiliation, but also ethnicity, were often perceived as determining factors for being able to operate a business, rather than performance. Moreover, the high number of corruption scandals and embezzlement of public funds in party-owned and party-affiliated enterprises raised questions as to the EPRDF's capacity to select and discipline businesses to ensure their contribution to the ruling coalition's development programme.

\section{NOTES}

1. Ethiopia has been undergoing rapid political changes since spring 2018 that have also affected the EPRDF's economic development policies. Initiatives for liberalisation and revisions of laws governing the private sector are two examples. While the alterations to previous policies indicate a rupture with the developmental state ideology previously embraced by the EPRDF, the direction in which economic policy is heading remains unclear. This article covers the period 2003-2017, tracing the EPRDF's attempt to build a developmental state, and it does not account for the rapid changes currently underway.

2. Following Leninist traditions, the EPRDF adopted the model of a vanguard party, understanding its mandate as ruling on behalf of the masses to implement revolutionary politics (Aregawi 2oog; Markakis 2011 ). Instead of popular participation, the focus of the EPRDF lay in popular mobilisation. In contrast to genuine participation, mobilisation did not allow the people to influence the EPRDF's political programme and was limited to mobilising resources (human, financial or political) to achieve it.

3. The role of the domestic private sector in Ethiopia's developmental state was, for example, assessed and discussed at the 'Democracy and the Future of Ethiopia's Developmental State' conference on 11 June 2019 . 
4. To guarantee anonymity and confidentiality, interviewees have been allocated numbers for citation purposes and their position and institutional affiliation have been omitted. Instead they have been divided into categories - civil servant, representative of chambers of commerce and sectoral associations, expert etc. - to render the analysis more transparent.

5. The Derg was the military council which ruled Ethiopia from 1974 to 1991.

6. During the Ethiopian Empire, Shewa Amhara controlled large parts of the country's political and economic resources and even during the Derg regime many elites were of Amhara origin (Abbink 2015 ).

7. Each Ministry is headed by a Minister who has state ministers working under him, responsible for the technical management of the ministry (Proclamation No. 916 2015:12).

\section{R E F E R E N C E S}

Abbink, J. 2015. 'The Ethiopian Revolution after 4o years (1974-2014): plan B in progress?', Journal of Developing Societies 31, 3: 333-57.

Altenburg, T. 2010. 'Industrial policy in Ethiopia', Discussion Paper. Bonn: Deutsches Institut für Entwicklungspolitik.

Amsden, A.H. 1992. Asia's Next Giant: South Korea and Late Industrialization. Oxford: Oxford University Press.

Aregawi, B. 2009. A Political History of the Tigray People's Liberation Front (1975-199I). Los Angeles, CA: Tsehai Publishing Imprint.

Arkebe, O. 2015. Made in Africa: industrial policy in Ethiopia. Oxford: Oxford University Press.

Bach, J.-N. 2011 . 'Abyotawi democracy: neither revolutionary nor democratic, a critical review of EPRDF's conception of revolutionary democracy in post-1991 Ethiopia', Journal of Eastern African Studies 5, 4: 641-63.

Berhanu, A. 2013. 'Political parties in business: rent seekers, developmentalists, or both?', Journal of Development Studies 49, $11: 1467-83$.

Birdsall, N.M., Campos, J.E.L., Kim, C.-S., Corden, W.M., MacDonald, L., Pack, H., Page, J., Sabor, R. \& Stiglitz, J.E. 1993. The Asian Miracle-Economic Growth and Public Policy. A World Bank Policy Research Report. New York, NY: Oxford University Press. http://documents.worldbank.org/curated/en/ $975^{\mathrm{o} 81} 4^{6824455^{\circ}}$ 798/Main-report.

Brautigam, D., T. Weis \& X. Tang. 2016. 'Latent advantage, complex challenges: industrial policy and Chinese linkages in Ethiopia's leather sector', China Economic Review 48: $15^{8-69}$.

Castells, M. 1992. 'Four Asian tigers with a dragon head: a comparative analysis of the state, economy and society in the Asian Pacific Rim', in R.P. Appelbaum \& J.W. Henderson, eds. States and Development in the Asian Pacific Rim. Newbury Park, CA: Sage, 33-70.

Clapham, C. 2018. 'The Ethiopian developmental state', Third World Quarterly 39, 6: $115^{1-65}$.

Directive to Proclamation 341. 2004. 'A Directive Issued to Implement Proclamation No of $341 / 2002$ of Chamber of Commerce and Sectoral Associations Council'. Federal Negarit Gazeta of the Federal Democratic Republic of Ethiopia.

Ethiopian Chamber of Commerce and Sectoral Associations (ECCSA). 2014. Five Year Strategic Plan, 20 I4/ I 5-2018/19. Addis Ababa: ECCSA.

ECCSA. 2019a. ECCSA's Members. http://ethiopianchamber.com/eccsa\%E2\%8o\%9gs-members.aspx, accessed 10.07.2019.

ECCSA. 2019 b. Structure of the Chamber System in Ethiopia. http://ethiopianchamber.com/structure-of-thechamber-system-in-ethiopia.aspx, accessed 10.07.2019.

Evans, P.B. 1995. Embedded Autonomy: states and industrial transformation. Princeton, NJ: Princeton University Press.

Gebreeyesus, M. \& M. Iizuka. 2012. 'Discovery of flower industry in Ethiopia: experimentation and coordination', Journal of Globalization and Development 2, 2: 1-25.

Geiger, M.T. \& L.C. Moller. 2015. 'Fourth Ethiopia Economic Update: Overcoming Constraints in the Manufacturing Sector'. World Bank Report Nr. 97916. Addis Ababa: World Bank Group, 1-75.

General Notice 9o. 29 April 1947. Negarit Gazeta.

Haggard, S. 1983. 'Pathways from the Periphery: The Newly Industrializing Countries in the International System (Korea, Taiwan, Mexico, Brazel, Hong Kong)'. PhD Thesis, University of California, Berkeley.

Johnson, C. 1982. MITI and the Japanese Miracle: the growth of industrial policy, 1925-1975. Stanford, CA: Stanford University Press.

Johnson, C. 1995. Japan, Who Governs? The Rise of the Developmental State. New York, NY: WW Norton \& Company. 
Johnson, C. 1999. 'The developmental state: odyssey of a concept', in M. Woo-Cummings, ed. The Developmental State. Cornell, CA: Cornell University Press, 32-6o.

Kim, E.M. 1997. Big Business, Strong State: Collusion and Conflict in South Korean Development, I960-1990. New York, NY: SUNY Press.

Kim, E.-Y. 1993. 'The developmental state and the politics of business interest associations: the case of the textile industry in South Korea', Pacific Focus 8, 2: 31-6o.

Krueger, A. 2004. "The Georgeous East': What the Asian Economies Can Teach the World'. Keynote Address. Harvard Project for Asian and International Relations (HPAIR) Business Conference. Shanghai: IMF.

Lal, D. 1998. 'Institutional Development and Economic Growth'. SSRN Scholarly Paper No. ID 185629. Rochester, NY: Social Science Research Network.

Lefort, R. 2012. 'Free market economy, "developmental state" and party-state hegemony in Ethiopia: the case of the "model farmers", Journal of Modern African Studies 5o, 4: 681-7o6.

Lucas, J. 1997. 'The politics of business associations in the developing world', Journal of Developing Areas 32 , 1: $71-96$.

Markakis, J. 201 1. Ethiopia - The Last Two Frontiers. Woodbridge: James Currey.

Meles, Z. 20o6. 'African Development: Dead Ends and New Beginnings'. Draft for discussion. Unpublished Dissertation, Erasmus University, Rotterdam.

Meles, Z. 2011 . 'States and markets: neoliberal limitations and the case for a developmental state', in A. Noman, K. Botchwey, H. Stein \& J.E. Stiglitz, eds. Good Growth and Governance in Africa: rethinking development strategies. Oxford: Oxford University Press.

Mesfin, G., N. Dihel \& G. Zerihun. 2018. 'The Inescapable Manufacturing - Services Nexus: Exploring the Potential of Distribution Services'. Addis Ababa: The World Bank.

'Minutes of the Annual General Meeting'. 17 February 1972. Addis Ababa: Ethiopian Chamber of Commerce.

Moon, S.-B. 2010. 'Demystifying the impasse of the Korea-Japan FTA: the pivotal role of big business associations in S Korea's trade policy', Journal of International and Area Studies 1 7, 2: 1-19.

Ministry of Trade and Industry (MoT), Girma Birru Minister \& Ethiopian Chamber of Commerce and Sectoral Associations (ECCSA), Eyessus Zafu President. 2010. 'Memorandum of Understanding Signed between the Ministry of Trade and Industry of the Federal Democratic Republic of Ethiopia and the Ethiopian Chamber of Commerce and Sectoral Associations'. Addis Ababa: MoT and ECCSA.

Park, S. 2009. 'Cooperation between Business Associations and the Government in the Korean Cotton Industry, 1950-70’, Business History $5^{1}$, 6: 835-53.

Pellerin, C.L. 2019. 'The Politics of Public Silence-Civil Society-State Relations under the EPRDF Regime'. PhD thesis, London School of Economics and Political Science.

Perry, M. 1997. Singapore: a developmental city state. Chichester: Wiley.

Planel, S. 2014. 'A view of a bureaucratic developmental state: local governance and agricultural extension in rural Ethiopia', Journal of Eastern African Studies 8, 3: 420-37.

Plummer, J., ed. 2012 . Diagnosing Corruption in Ethiopia: perceptions, realities, and the way forward for key sectors. Herndon: World Bank Publications.

Private Sector Development Hub. 2013. 'Revisiting the Ethiopian Private Sector Associative Formats with a View of Fostering a Stronger Private Sector'. Addis Ababa: ECCSA, ACCSA \& Sida.

Proclamation No. 148. 1978. 'Chambers of Commerce Proclamation'. Addis Ababa: Negarit Gazeta.

Proclamation No. 341. 2003. 'Chambers of Commerce and Sectorial Association Establishment Proclamation'. Addis Ababa: Federal Negarit Gazeta of the Federal Democratic Republic of Ethiopia.

Proclamation No. 916. 2015. 'Definition of Powers and Duties of the Executive Organs of the Federal Democratic Republic of Ethiopia Proclamation'. Addis Ababa: Federal Negarit Gazeta of the Federal Democratic Republic of Ethiopia.

Segers, K., J. Dessein, J. Nyssen, H. Mitiku \& J. Deckers. 2008. 'Developers and farmers intertwining interventions: the case of rainwater harvesting and food-for-work in Degua Temben, Tigray, Ethiopia', International Journal of Agricultural Sustainability 6, 3: 173-82.

Seid, Y., A.S. Taffesse \& S.N. Ali. 2016. 'African lions: Ethiopia - an agrarian economy in transition'. No. I25, O10, O12. Helsinki: Brookings and UNU-WIDER.

Spielman, D.J. 2008. 'Encouraging Economic Growth in Ethiopia: Perspectives on Agricultural Input Markets, Agricultural Extension and Advisory Services, and Agricultural Education and Training'. Part of the DFID Funded Study Understanding the Constraints to Continued Rapid Growth in Ethiopia: The Role of Agriculture. International Service for National Agricultural Research (ISNAR), International Food Policy Research Institute.

Sutton, J. \& N. Kellow. 2010. 'An Enterprise Map of Ethiopia'. London: International Growth Centre. 
Taffara, D. 20o6. Minutes of an Ethiopian Century. Addis Ababa: Shama Books.

Vaughan, S. 2011. 'Revolutionary democratic state-building: party, state and people in the EPRDF Ethiopia', Journal of Eastern African Studies 5, 4: 619-40.

Vaughan, S. \& M. Gebremichael. 2011. 'Rethinking Business and Politics in Ethiopia: The Role of EFFORT, the Endowment Fund for the Rehabilitation of Tigray'. London: UK Department for International Development and Irish Aid.

van Veen, E. 2016. 'Perpetuating Power-Ethiopia's Political Settlement and the Organization of Security'. CRU Report. The Hague: Clingendael - Netherlands Institute of International Relations.

Wade, R. 1988. 'State intervention in "outward-looking” development: neoclassical theory and Taiwanese practice', in G. White, ed. Developmental States in East Asia. London: Palgrave Macmillan, 3o-67.

Wade, R. 2003. Governing the Market: Economic Theory and the Role of Government in East Asian Industrialization. Princeton, NJ: Princeton University Press.

Weis, T. 2014. 'Dominant parties and the private sector in sub-Saharan Africa: a typology of approaches', Zeitschrift Für Vergleichende Politikwissenschaft 8, 3-4: 263-81.

Weis, T. 2016. 'Vanguard Capitalism: Party, State, and Market in the EPRDF's Ethiopia'. PhD Thesis, Oxford University.

\section{Fieldwork notes}

Fieldnotes, C.P. 4 July 2016a. Chamber Meeting with the AACCSA and the Oromia Chamber of Commerce and Sectoral Associations in Adama (unpublished fieldwork).

Fieldnotes, C.P. 10 June 2016b. 'AACCSA Annual Meeting' (unpublished fieldwork).

Fieldnotes, C.P. 2 April 2016c. 'Good Corporate Governance Institute Annual Meeting' (unpublished fieldwork).

Fieldnotes, C.P. 3 January 2016d. 'AACCSA Trade Fair Closing Ceremony' (unpublished fieldwork).

Fieldnotes, C.P. 18 October 2016e. 'Conference on Sustainable Manufacturing Matters for Ethiopia and Africa’ (unpublished fieldwork).

\section{Newspapers}

Addis Business, Addis Ababa.

Addis Business. May 1998. Vol. 1, No 5 .

Addis Business. June 1998. Vol. 1, No 6.

Addis Business. April 1999. Vol. 2, No 4.

Addis Business. December 1999. Vol. 2, No 12.

Addis Business. April 200o. Vol. 3, No 4.

Addis Business. February 2003. Vol. 6, No 2.

Addis Business. August 2005. Vol. 7, No 20.

Mesfin, Z. May 2015. 'Private Sector Issues Identified for GTP II Inclusion'. Addis Business.

Shitahun, S. October 2015 . 'Are MSEs a Springboard to Jack Industrialization Up?', Addis Business.

Addis Fortune. Addis Ababa.

Addis Fortune. 2009. 'Battling for Commerce History, Yet Pieces of Same Future Puzzle', 9, 463.

Bewket, A. 2013. 'Quorum Qualms Mare Chamber Assembly'. Addis Fortune 14, 712.

Dawit, E. 2016. 'National Chamber Election on Hold'. Addis Fortune 17, 866.

Mikiyas, T. 2016. 'Chamber Elects Elias President, Members Cry Foul'. Addis Fortune 1 7, 858.

Samson, B. 2017. 'Government Instructs Chambers to Re-Elect Presidents'. Addis Fortune 17, 879.

Teshome, B. 2014. 'Why Integrity Matter to Addis Chamber', Addis Fortune ${ }_{15}, 736$.

Addis Tribune. Addis Ababa.

Staff Reporter. 3o April 1999. 'Ethiopia: Chamber Official Says AACC Committed to Improve Relations with ECC'. Addis Tribune.

Ethiopian Trade Journal. Addis Ababa

Ethiopian Trade Journal. 1970. Vol. VII, No. 2.

Nigdna Limat, Addis Ababa.

Nigdna Limat. April $1992 a$.

Nigdna Limat. May $1992 b$.

Nigdna Limat. July 1993.

Nigdna Limat. May 1994 a. 
Nigdna Limat. March 1994 b.

Nigdna Limat. January 1989. No 59.

Nigdna Limat. June 1988 . No 53 .

Nigdna Limat. September 1996. Vol XVII, No 5 .

The Reporter. Addis Ababa.

Asrat, S. 11 December 2016. 'Chamber in Chaos', The Reporter.

Birhanu, F. 12 November 2016. 'The Chamber in Its Worst Shape - Interview with Kebur Ghenna'. The Reporter.

Yemisrach, B. (27 April 1999) 'Ethiopia: The New Millennium's Chamber', The Reporter.

\section{Interviews}

Interviewee Nr. 20. 2015 , Employee, Chambers of Commerce and Sectoral Association, Addis Ababa, 13.11 .2015 .

Interviewee Nr. 20. 2016a, Addis Ababa, 10.3.2016.

Interviewee Nr. 20. 2016b, Addis Ababa, 16.5.2016.

Interviewee Nr. 20. 2016c, Addis Ababa, 7.11.2016.

Interviewee Nr. 38. 2016, Employee, Chambers of Commerce and Sectoral Association, Addis Ababa, 2.12 .2016 .

Interviewee Nr. 39. 2016, Employee, Chambers of Commerce and Sectoral Association, Addis Ababa, 2.12 .2016$.

Interviewee Nr. 40. 2016, Employee, Chambers of Commerce and Sectoral Association, Addis Ababa, 2.12.2016.

Interviewee Nr. 42. 2016, Employee, Chambers of Commerce and Sectoral Association, Addis Ababa, 15.2 .2016$.

Interviewee Nr. 46. 2016, Consultant, Chambers of Commerce, Addis Ababa, 17.2.2016.

Interviewee Nr. 47. 2016, Employee, Chambers of Commerce and Sectoral Association, Addis Ababa, 17.02 .2016$.

Interviewee Nr. 55. 2016, Employee, Chambers of Commerce and Sectoral Association, Addis Ababa, $3 \cdot 4 \cdot 2016$.

Interviewee Nr. 56. 2016, Consultant, Chambers of Commerce, Addis Ababa, 3.4.2016.

Interviewee Nr. 57. 2016, Employee, Chambers of Commerce and Sectoral Association, Addis Ababa, $3 \cdot 4 \cdot 2016$.

Interviewee Nr. 59. 2016, Member Organisation, Chambers of Commerce and Sectoral Association, Addis Ababa, 3.7.2016.

Interviewee Nr. 6o. 2016, Member Organisation, Chambers of Commerce and Sectoral Association, Addis Ababa, 3.10.2016.

Interviewee Nr. 62. 2016a, Civil Servant, Addis Ababa, 3.10.2016.

Interviewee Nr. 62. 2016b, Addis Ababa, 3.11.2016.

Interviewee Nr. 66. 2016. International Donor Representative, Addis Ababa, 22.3.2016.

Interviewee Nr. 70. 2016. President, Sectoral Association, Addis Ababa, 1 7.3.2016.

Interviewee Nr. 75. 2016. Consultant, Chambers of Commerce, Addis Ababa, 22.3.2016.

Interviewee Nr. 76. 2016. International Donor Representative, Addis Ababa, 25.5.2016.

Interviewee Nr. 81. 2016a. Former President, Chambers of Commerce and Sectoral Association, Addis Ababa, 26.5.2016.

Interviewee Nr. 81. 2016b, Addis Ababa, 13.13.2016.

Interviewee Nr. 82. 2016. Member, Chambers of Commerce and Sectoral Association, Addis Ababa, 30.5 .2016$.

Interviewee Nr. 89. 2016. Former President, Chambers of Commerce and Sectoral Association, Addis Ababa, 6.7.2016.

Interviewee Nr. 91. 2016. Employee, Chambers of Commerce and Sectoral Association and Civil Servant, Addis Ababa, 16.6.2016.

Interviewee Nr. 92. 2016. Secretary General, Chambers of Commerce and Sectoral Association, Addis Ababa, 16.6.2016.

Interviewee Nr. 103. 2016. Secretary General, Chambers of Commerce and Sectoral Association, Addis Ababa, 30.5.2016.

Interviewee Nr. 104. 2016. President, Chambers of Commerce and Sectoral Association, Addis Ababa, 30.6 .2016 . 
Interviewee Nr. 107. 2016. Civil Servant, Addis Ababa, 13.10.2016.

Interviewee Nr. 111. 2016. Former President, Chambers of Commerce and Sectoral Association, Addis Ababa, 14.10.2016.

Interviewee Nr. 120. 2016. Politician, Addis Ababa, 26.10.2016.

Interviewee Nr. 121. 2016. President, Chambers of Commerce and Sectoral Association, Addis Ababa, 25.10.2016.

Interviewee Nr. 126. 2016. President, Sectoral Association, Addis Ababa, 1.11.2016.

Interviewee Nr. 129. 2016. President, Sectoral Association, Addis Ababa, 3.11.2016.

Interviewee Nr. 132. 2017. Consultant, Private Sector, Addis Ababa, 21.2.2017.

Interviewee Nr. 151. 2018. Employee, Chambers of Commerce and Sectoral Association, Addis Ababa, 26.2.2018.

Interviewee Nr. 153. 2018. Civil Servant, Addis Ababa, 27.2.2018. 